Article

\title{
'Deep Learning' in Studies of Religion and Worldviews in Norwegian Schools? The Implications of the National Curriculum Renewal in 2020
}

\author{
Oddrun M H Bråten ${ }^{1, *(\mathbb{D})}$ and Geir Skeie ${ }^{2}$ D \\ 1 Department of Teacher Education, Norwegian University of Science and Technology (NTNU), \\ 7491 Trondheim, Norway \\ 2 Department of Cultural Studies and Languages, University of Stavanger, 4010 Stavanger, Norway; \\ post@uis.no \\ * Correspondence: oddrun.m.braten@ntnu.no or postmottak@ntnu.no
}

Received: 1 September 2020; Accepted: 26 October 2020; Published: 4 November 2020

\begin{abstract}
From 2020, the National Curriculum in Norway has been totally renewed for primary, secondary, and upper secondary education. This includes the introduction of such new concepts as 'deep learning' and 'core elements' in school education. In this article, we unpack the significance of the reform for studies in religion and worldviews in Norwegian schools. We explore continuities and changes by looking at general educational trends and debates and how they become significant, specifically for the study of religion and worldviews in schools. While the changes may stem from international trends, they have been formed in a Norwegian discourse that also draws on traditions from previous curricula. Three interdisciplinary topics have been introduced: 'health and life skills', 'democracy and citizenship', and 'sustainable development'. Emphasis is placed on competence-oriented relevance and less on the traditional classroom learning of 'facts'. Our research question is: Which continuities and which changes are found when comparing studies of religion and worldviews in the previous and the new curricula? Our hypothesis is that continuities stem from national traditions while incentives to change are connected to rapid social change that is also reflected in supranational developments in education. Our methodology is a contextual presentation and discussion of studies of religion and worldviews, where the context we are considering includes both national and international discourses. Our objective is to inform a broader audience about recent developments in the Norwegian school, as well as to bring together important elements in this reform in a focused discussion on the framework for studies of religion and worldviews in Norwegian schools today. We identify both continuity and change, along a subject-specific-general-educational policy axis and along a national-international axis. The continued relevance of teaching about religion and worldviews in schools is strengthened in the reform, because of the potential for significant contributions to general aims of education now reflected in 'core elements', including for continued development of a functioning democracy.
\end{abstract}

Keywords: deep learning; big ideas; religious education; curriculum; worldviews

\section{Introduction}

From 2020, the National Curriculum in Norway has been totally renewed for primary, secondary, and upper secondary education. A new foundational text, "Core curriculum-values and principles for primary and secondary education", was adopted in $2017 .{ }^{1}$ This is expected to be a more active part

1 See the official English version: https://www.udir.no/lk20/overordnet-del/?lang=eng (Downloaded 26 April 2020). 
of the planning of teaching than the previous core curriculum from 1993, thus having more impact on practical teaching. A new element of this broad reform is that the subject curricula are focused on 'core elements' more than on detailed learning content, and there is a new emphasis on 'deep learning'. 'Deep learning' throughout the academic world normally is associated with Artificial Intelligence (AI). According to the white paper preceding this reform from 2014, called the Ludwigsen 1 report (NOU 2014:7 2014), the Norwegian term 'dybdelæring', deep learning or in-depth learning as it is sometimes referred to, has been established as an education policy term that is an important part of the new reform. Here it has a particular meaning explained by the educational authorities as something completely different from its well-established meaning within computer science. As a new and key policy term, it is also being discussed in Norway, but still not in relation to how the term is used within computer science. Also new within this reform, on a general level, is the introduction of three interdisciplinary topics: health and life skills, democracy and citizenship, and sustainable development.

In this article we use extended case theory (Burawoy 1991) to analyse developments in the curriculum, and here 'case' must be considered in a wider context, such as globalisation being a contextual factor for education today. A distinction should be made between the close context of a case, here Norwegian Educational Policy as the context for studies of religion and worldviews in schools, and a wider context that includes notable trends within supranational regimes today, such as "big ideas" in education (Kallo and Rinne 2006; Stone-Wiske 1998). Cases should be considered in relation to both a national and a supranational dimension (Bråten 2013). Furthermore, in reference to Goodlad and Su (1992), also distinguishes between levels of curriculum on an institutional curriculum level and a societal curriculum level, and, of less significance in this article, also curriculum in the sense of what goes on in actual teaching and learning.

While earlier curriculum changes in the primary and lower secondary school religion subject, in 2002, 2008, and 2015, were related to subject-specific debates, the changes in 2006 and 2020 have followed general curricular reforms. Influences from both subject-specific debates and educational policies may come from outside of national contexts. This means that changes in a particular school subject can be described by referring to two axes, where one continuum goes between subject-specific and general-educational developments, and the other between nation-specific and international/supranational developments. By supranational we mean developments that transcend the national contexts, for example involving the EU or the Council of Europe (Bråten 2013, pp. 47-52). The two axes are illustrated in Figure 1.

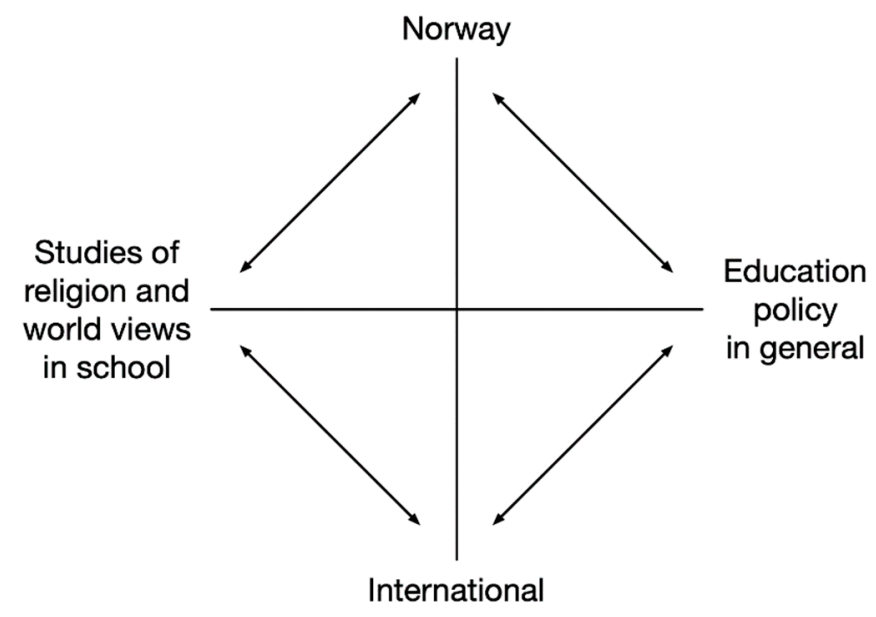

Figure 1. Axes of influence on religious education curricula.

The aim here is to investigate what shaped the latest changes in Norwegian religion and worldview education in school. We will show that some elements in the present reform did not originate in Norway but are part of an international flow of educational policies. The research question for the 
article is: Which continuities and which changes are found when comparing studies of religion and worldviews in the previous and the new curricula?

We start by describing the new curriculum as part of the Norwegian context, then discuss the role of "relevance and big ideas" in this connection. Following this, we describe further elements of the general reform, the "core elements and interdisciplinary topics", and finally "competence and deep learning". Finally, we discuss our findings in terms of developments in Norwegian religion and worldview education in an international context. We will draw on the two-axes model in Figure 1 when we discuss important aspects of the new curriculum.

\section{The New Curriculum as Part of the Norwegian Context}

The Norwegian national curriculum covers all school subjects, including what is called 'Christianity, Religion, Worldviews and Ethics' for primary and lower secondary schools, and 'Religion and Ethics' for upper secondary school. ${ }^{2}$ As the number of private schools in Norway is very low, with $6.5 \%$ of pupils in total, ${ }^{3}$ the national curriculum is the institutional curriculum for the vast majority of pupils in Norway in a comprehensive unitary school system (Bråten 2013; Skeie and Bråten 2014).

The study of religion and worldviews in Norwegian schools is mainly given as a small compulsory separate subject with 580 lessons (60 min each) allocated in primary and lower secondary education; 427 for years $1-7$ and 153 for years $8-10 .{ }^{4}$ On average, this means roughly one and a half lessons per week in years 1-7 and about two lessons per week in lower secondary school (years 8-10). Upper secondary school has been allocated 84 lessons in the third and final year of study (Utdanningsdirektoratet 2019). Religion may, however, also be covered to some degree in other subjects, such as history lessons and interdisciplinary teaching.

Religion and worldview education in Norwegian primary and lower secondary school adopted its current form in 1997 when an integrative subject was introduced. The subject was constructed from two former parallel subjects, where the dominant subject was 'Knowledge about Christianity', and the more marginal option was Worldviews Education (Bråten 2018). ${ }^{5}$ The intention behind integrating these two into a new subject for all pupils was to end the former confessional tradition of 'Knowledge about Christianity' and to establish what the Norwegian Education Act describes as an 'ordinary school subject'. Nonetheless, while it was specified that this was an ordinary school subject, the aims and content were questioned right from the subject's inception and were a source of controversy. Exemptions could only be granted from certain activities that from the point of view of pupils and parents were considered religious or in breach of their own worldview. The curriculum was challenged in court both in Norway and internationally, which led to key points being changed in 2008 after a verdict in the European Court of Human Rights (Lied 2009).

The inclusive nature of the subject drew more on the ideas behind the 'neutral' (secular) Worldviews Education, but large parts of the content had strong similarities with the earlier 'Knowledge about Christianity'. It was explicitly stated that the subject should reflect the Christian national heritage in Norway. The integrated subject was a compromise, initially named 'Christianity with Orientation about other Religions and Worldviews'. Several Norwegian scholars have argued that this was a political device for integration in an increasingly worldview-pluralistic Norway, but also a means to ensure enculturation into mainstream Norwegian-ness and the country's Christian cultural heritage (Bråten 2013; Gravem 2004; Iversen 2012; Skeie 2007; Skeie and Bråten 2014). Since 2012, Humanism

2 The Norwegian terms are 'Kristendom, Religion, Livssyn og Etikk' (KRLE) and 'Religion og Etikk' (RE).

3 Statistics Norway: https://www.ssb.no/utdanning/statistikker/utgrs (accessed 23 March 2020). Private schools have to offer an alternative pedagogy (e.g., Waldorf or Montessori) or offer a distinct religious or worldview profile. In practice this means Christian, there are presently no Muslim or other non-Christian religiously based schools in Norway.

4 In comparison, social studies have been allocated $634 \mathrm{~h}$; English as a foreign language 588; physical education 701; Norwegian language and literature 1372; mathematics 888 (all years 1-10)

5 Norwegian terms: 'Kristendomskunnskap' and 'Livssynsorientering'. 
has become an official part of the 'national heritage' and has been introduced into the Constitution and the Education Act as a source of basic values for Norwegian schools. Values named in the renewed Act's preamble from 2008 are: respect for human dignity and nature, freedom of thought, love of one's neighbour, forgiveness, equality, and solidarity. It is noted in the Education Act that these values are also found in other religions and worldviews, and that they are anchored in basic human rights. ${ }^{6}$

After 1997, controversies about the nature of the religion and worldview subject are reflected in the frequent change of names; from 2002-2008 it was 'Knowledge of Christianity, Religions and Worldviews and from 2008-2015 'Religions, Worldviews and Ethics'. While this change was justified by the verdict in Strasbourg, the name was changed again in 2015 when the term Christianity was re-introduced. Since 2015, the name has therefore been 'Christianity, Religions, Worldviews and Ethics'. This change came as result of a shift from a left-centre to a centre-right national government. Arguments behind this change stated that without this revision, the Christian tradition would not be sufficiently represented. There is no room here to delve into the political debates on this, but there was a clear connection to each political party's general policies on religion and society (Andersland 2019). This decision of course did not satisfy all stakeholders and the debate continues (Bråten and Everington 2019). On the other hand, there have been no controversies over the subject 'Religion and Ethics' in upper secondary education, where the name has been unchanged since 1996 (from 1976-1996 it was called 'Religion') (Andreassen and Olsen 2015).

One element of continuity between the previous and new curricula is therefore that teaching about Christianity is given special priority, to the point of being allocated about half of the total lesson time. The preservation of Norway's cultural heritage is one argument for this emphasis, and another is that the majority of Norwegians, now $68 \%$, are members of the Church of Norway. ${ }^{7}$ This number is steadily decreasing, however. The new curriculum calls for a broad exploration of 'religion and worldviews', but explicitly mentions Christianity, indigenous religion, Judaism, Islam, Buddhism, Hinduism, Sikhism, new religions, and secular humanism as a worldview. These should all be addressed separately and seen in connection with each other. The explicit mentioning of indigenous religion and Sikhism is new as is the phrase 'separately and in connection'. A third topic area, ethics and philosophy, is found in both the old and the new curricula.

For Religion and Ethics in upper secondary education, the main topic areas before the present reform were 'knowledge of religion and critique of religion, Islam and one additional religion of choice, Christianity, and philosophy, ethics and secular humanism as a worldview' (Utdanningsdirektoratet 2020). The new curriculum has 14 competence aims, all listed under the same heading. The content of the subject has been thoroughly revised, with new competence aims, such as 'explore and discuss how religion is part of historical processes of change globally and nationally' and 'explore and analyse how religions and worldviews are expressed in media and popular culture'. A special mention that Christianity and Islam should be included is continued from the former edition.

\section{Relevance and Big Ideas}

Which knowledge and skills should be considered most important, and what is so relevant that it should be included in the school curricula? The present educational reform intends, as educational reforms generally do, to make school relevant for the future (Geir Skeie 2020). One line of argument is that when information and 'facts' are available instantly and everywhere, the role of formal education comes into question. Bearing this in mind, what is the specific relevance of the study of religion and worldviews in schools for society and for each pupil?

\footnotetext{
https://lovdata.no/dokument/NL/lov/1998-07-17-61/KAPITTEL_1\#\%C2\%A71-1 (Downloaded 24 May 2020).

https://www.ssb.no/statbank/table/12025/tableViewLayout1/ (Downloaded 21 May 2020). This number has shrunk in later years.
} 
Among the theoretical perspectives that have been offered to better determine what is most relevant in education is the concept of 'big ideas' (Harlen 2010, 2015). This approach was first developed as part of science education and emphasises pupils' understanding as a criterion for selecting teaching materials and methods. Here, 'understanding' refers to the ability to use knowledge in new situations, which also connects to the term 'deep learning' (Stone-Wiske 1998). We find this terminology in the Norwegian Official Reports to the Parliament for the present educational reforms (NOU 2014:7 2014; NOU 2015:8 2015). As a result of this perspective, it was suggested as part of the process of renewal to formulate 'core elements' for each school subject before the subject curricula themselves were formulated. ${ }^{8}$ Establishing these core elements is a means to determine what is most important to learn in a subject area. Since one main aim of the reform is that what is taught and learned should be relevant, in relation to new technology, new knowledge and new challenges today and in the future, pupils should not focus on learning 'facts' but engage in 'deep learning', which also means to learn how to learn, to be able to use knowledge in new situations and to attain a certain level of metacognition.

Initially, the focus on 'big ideas' and relevance led to the suggestion to abandon the school subjects as discrete entities and to construct areas of knowledge incorporating the former subjects. This was seen as a way to put the focus on what was relevant knowledge rather than becoming bogged down in the traditional subject disciplines and their content inventories. The government, however, did not adopt this suggestion and decided to keep the subjects and rather introduce the concept of big ideas, relevance, and deep learning into the curriculum construction process. These are elements of general educational policies collected from elsewhere that have been 'borrowed' by the Norwegian authorities (Steiner-Khamsi 2004), as illustrated by the lower right quadrant in Figure 1. However, as we shall see, the 'big-ideas' concept has also been introduced in other national contexts, and is explored further in our field of interest, the study of religion and worldviews in school (Wintersgill 2015).

In the following we shall proceed by taking a closer look at how 'big ideas' have been operationalised by 'core elements' in this reform, and in religion and worldviews subjects specifically. We will also present the new interdisciplinary topics in some more detail, looking into their implications for our area of interest.

\section{Core Elements and Interdisciplinary Topics}

As mentioned above, the concept of 'core elements' in the general part of the new Norwegian subject curricula refers to assumptions about 'big ideas', referring to 'what pupils need to learn in order to master and use the subject' and consists of 'core concepts, methods, ways of thinking, knowledge areas and ways of expression in the subject' (Kunnskapsdepartementet 2016). In the process of curricular renewal, this was applied to all school subjects and core elements were developed for each school subject prior to the process of constructing the subject curricula. The idea was to ensure that the final product remained tuned to the main intentions behind the reform, and that the subject curricula would be short and to the point. Another aim was also to have a dynamic text that could be relevant into the future.

Core elements in religion and worldview education, identical for primary, secondary and upper secondary schools, are specified in the Norwegian context as follows (Table 1): ${ }^{9}$

8 In Norwegian, 'kjerneelementer'.

9 There is a short explanation of each core element included in the curriculum with a brief summary in the table. Translation by authors, based on official electronic version in Norwegian: https://www.udir.no/lk20/rle01-03/om-faget/kjerneelementer (Downloaded 26 March 2020). 
Table 1. Core elements in religion and world view education.

\begin{tabular}{ll}
\hline Core Element & Summary of Issues Included \\
\hline Knowledge of religions and worldviews & $\begin{array}{l}\text { Local and global perspectives, tradition, group and } \\
\text { individual level, historical and social change }\end{array}$ \\
\hline $\begin{array}{l}\text { Exploring religions and worldviews using different } \\
\text { methods }\end{array}$ & $\begin{array}{l}\text { Complexity, diversity, critical reflection regarding } \\
\text { sources, norms and power of definition }\end{array}$ \\
\hline Exploring existential questions and answers & $\begin{array}{l}\text { Ways people have approached questions of meaning, } \\
\text { identity, and the way they see the world through } \\
\text { religions, worldviews, ethics. Room for reflection and } \\
\text { wonder as well as disagreement }\end{array}$ \\
\hline Ability to adopt the perspectives of others & $\begin{array}{l}\text { Develop own positions, encounter insider/outsider } \\
\text { perspectives, dialogue on differences, diversity and } \\
\text { inclusion, gender perspectives, indigenous } \\
\text { perspectives, mutual respect }\end{array}$ \\
\hline Ethical reflection & $\begin{array}{l}\text { Identify and discuss ethical dilemmas, ethical } \\
\text { reflection including argumentation, models and } \\
\text { concepts dealing with conflicts }\end{array}$ \\
\hline
\end{tabular}

In the previous curriculum from 2006, the competence aims were closely linked to main areas of knowledge, while in the new curricula, they are linked to the core elements. The taxonomy of the latest curriculum thus has more emphasis on the process of learning and understanding, while the 2006 curriculum had more focus on acquiring knowledge.

Another key aspect of the curricular renewal in 2020 is the introduction of three 'interdisciplinary topics': Health and life skills, Democracy and citizenship, and Sustainable development. The intention behind this is to ensure that the education has relevance in the face of the broad challenges that humanity is facing. Here we see the presence of a global dimension, where broad political, social, and environmental challenges are brought to the forefront in Norwegian education. This can therefore be identified as an element along the vertical Norway-International axis (Figure 1). The core elements are unique to each subject, while interdisciplinary topics and basic skills are the same across subjects, ${ }^{10}$ and therefore in effect elements that can be placed along the general-subject specific policy axis as well. The subject curriculum explains what the distinct subject contributes to the challenges related to the three interdisciplinary topics.

The interdisciplinary topics, already proposed in 2015, were intended to bridge between subjects and encourage collaboration across subjects. This is similar to the way the value-base is supposed to bridge between subjects and to encourage collaboration. The subject curricula even explain what the distinct contribution of the individual subject is towards the realisation of the value base. Again, the impact of general policy developments is that they add significant new elements to what the studies of religion and worldviews should be about.

The descriptions of these interdisciplinary topics balance individual and collective dimensions as well as normative and descriptive elements. 'Democracy and citizenship' introduce pupils to their rights and obligations as citizens and prepares them to participate in democratic processes, including training in handling differences. This topic area also highlights the relationships between the majority and minorities and the development of democracy. Here, the religion and worldview education curriculum emphasise its contribution to ethical reflection and the development of the ability to be attentive to others' views. 'Sustainable development' focuses on the importance of making informed and responsible choices in personal life based on environmental awareness. It draws on the broad scope of sustainability goals, including resources, climate, demography, technology and education, and their

10 Basic skills are: Reading, writing, numeracy, oral skills and digital skills. These were part of the curriculum in 2006 and have been retained in 2020 . 
global consequences. Religion and worldview education encourage pupils to explore the ethical and existential aspects of sustainable development. 'Health and life skills' refers to personal choices in terms of lifestyle and values, identity and health choices, but these are also linked to relationships with others and broader social issues influencing daily life. The learning of life skills, we could note, has long been an aspect of religion and worldview education, for instance through the teaching of ethics. A new feature in general education in Norway is that this has now been explicitly made into a topic in all subjects. Formally, school values should permeate all school activities, but religion and worldview education has so far had a special role in this. For religion and worldview educators it is now interesting to observe that 'the importance of meaning in life' is mentioned in this section of the Core Curriculum (Government 2017). Here, the word 'meaning' is used for what might be described as existential issues, though linked to health rather than to religion. Here, we see that an element has been shifted from the specific subject area to the general educational area.

Taken together, the interdisciplinary topics combine knowledge and values that contribute to the daily mastery of life and are possible arenas for asking existential questions that are important for the future. Thus, the interdisciplinary topics can be said to contribute to the formation of worldviews among pupils. 'Worldview' is a concept of varied usage and meaning, and is found in different scholarly traditions, different languages, and different contexts (Kooij 2016). Evolutionary and biologically grounded, it can be seen as referring to the meaning-making capacity of humans and the capacity to understand the world in a way that enables them to act in the world (Taves 2020). Historically, in the Norwegian curriculum we find both broad and narrow meanings of the term. The narrow meaning can be traced to the way secular humanism is treated as a kind of prototype 'worldview' (Bråten 2018; Schjetne and Hansen 2019) in a similar manner as 'Christianity' has prototyped 'religion' in a world-religions paradigm (Saler 2009; Anker 2017).

In Christianity, Religions, Worldviews and Ethics we still find 'worldviews' used in a narrow sense, e.g., in the competence aims after year 10, to 'explore and present central ideas of secular humanism and other non-religious worldviews'. A slightly less narrow sense is when it is used to refer to secular/non-religious worldviews in general, for instance Aadnanes has a broad description in which worldviews could be either religious or secular, i.e., a broad inclusive category (Aadnanes 2012). He also distinguishes between worldview traditions, which can be religions, and personal worldviews, and which can also be both religious and secular (see also Kooij 2016). The competence aims in Christianity, Religions, Worldviews, and Ethics from 2020 also include such aims as, 'to reflect on existential questions associated with growing up in a plural and global society' (after year 10); 'to reflect on existential questions connected to the way people live, living conditions and the future of the planet (after year 7) and 'to talk about human dignity, respect and tolerance and what it means for how we live together' (after year 4). These aims are closely connected to the interdisciplinary topics and contain elements that could contribute to the development of the personal worldviews of pupils.

We would argue that while learning life skills continues to be part of religion and worldview education, the conditions for this are new, considering how this issue has now shifted towards the general-educational-policy pole on the axis as outlined in Figure 1. Thus a general trend in educational policy may fuel an ongoing debate on the teaching of religion and worldviews in schools with respect to whether there should be learning 'about' only, or also 'learning from' religions (Grimmitt 1987). Historically, this debate is related to the emancipation from religious education in the sense of religious inculcation of a specific religion, in Norway predating the 1997 reform.

From these issues related to subject content, we proceed to explore further new elements in the general reform that are of a more educational nature: competences and deep learning, and what they mean for the study of religion and worldviews in Norwegian schools.

\section{Competences and Deep Learning}

The present educational reform focuses on 'competence' as the outcome of education and uses this as the key concept to describe what education should achieve, complemented by a number of 
qualifiers. The understanding of competences in the 2020 curriculum draws heavily on the concept of 'deep learning', which should not be confused with 'deep learning' in research on Artificial Intelligence (LeCun et al. 2015), but should rather be seen as a reaction to issues raised by the previous reform. This issue is very clearly situated towards the Norway end of the pole rather than the international end on the vertical axis, especially when it comes to the use of concepts. We would argue, however, that when it comes to content and meaning, it obviously also connects to international debates in and about education.

In the core curriculum, Section 2, relating to what competence in school subjects should mean, 'deep learning' is explained in the following way:

School must provide room for in-depth learning so that the pupils develop understanding of key elements and relationships in a subject, and so they can learn to apply subject knowledge and skills in familiar and unfamiliar contexts. In their work in the subjects, the pupils shall be given tasks and participate in varied activities with increasing complexity. In-depth learning implies applying knowledge and skills in different ways so that over time the pupils will be able to master various types of challenges in the subject, individually and in interaction with others. ${ }^{11}$

The curriculum reform of 2006 was termed a competence reform, emphasising 'knowledge promotion', as it was called in English, and the content was described in terms of what the pupils should learn (competence aims) rather than what the teachers should teach. In the Core Curriculum of 2020, 'competence' is defined more broadly by underlining:

The ability to acquire and apply knowledge and skills to master challenges and solve tasks in familiar and unfamiliar contexts and situations. Competence includes understanding and the ability to reflect and think critically. (p. 13)

Here, competence seems in part to complement 'Bildung', understood as the acquisition of cultural knowledge as a basis for the further development of one's own personality, ${ }^{12}$ and in part it seems to include it. This ambiguity can be interpreted as a desire to find a balance between a narrow, more instrumental understanding of 'competence' and a broader, more comprehensive one.

The curriculum of 2020 has an emphasis on formative assessment that promotes pupils' learning. The government regulation on assessment states that the purpose of assessment in subjects is to promote learning processes and to assess the pupil's competence (... ) in the process of learning and at the end of the subject learning'. ${ }^{13}$ Pupils have the right to both assessment for learning (formative assessment) and to have their qualifications assessed (summative assessment). The first type of assessment is part of the learning process, where quality feedback and teacher guidance are important, while summative assessment measures the learning outcome. These formulations from the assessment guidelines reveal the tension between the school's intertwined purposes, as described by Biesta: qualification, socialization, and subjectification (Gert Biesta 2010, pp. 11-27). In other words, there is a body of knowledge that is to be learned, there is a social context for that learning, and that may or may not facilitate the learner's ability to use what is learned in new contexts, such as cross-curricular school learning or, in their unpredictable future lives.

In the Official Reports (NOU 2014:7 2014; NOU 2015:8 2015) preceding the publishing of the final curricular texts and in the subsequent Proposition to Parliament (Kunnskapsdepartementet 2016),

11 See core curriculum English version, p. 11: https://www.udir.no/Udir/PrintPageAsPdfService.ashx?pdfld=150459\&lang=eng (Downloaded 26 March 2020).

12 'Bildung' in German, or 'danning' in the Nordic languages. In (Bråten 2013, e.g., p. 99), "Generic formation" has been used as a translation into English, but there is no good equivalent term in English. Alberts (2007, pp. 56-57) suggests that 'Bildung includes the acquisition of cultural knowledge as a basis of a further development of one's own personality' and that the German concepts of 'bildung' and 'Erziehung' are meaningfully integrated in the English concept of "Education"'.

13 Vurderingsforskriften, see Norwegian Acts, Lovdata: https://lovdata.no/dokument/SF/forskrift/2006-06-23-724/KAPITTEL_4\# KAPITTEL_4 (Downloaded 26 March 2020) (authors' translation). 
the concept of 'deep learning' was introduced as a key concept to describe the intended learning in and across subjects. This was based on referenced research into pupils' learning, including Sawyer, who writes about 'learning knowledge deeply' as opposed to 'traditional classroom practices' (Sawyer 2006). In the official report NOU 2014:7, deep learning is presented as being closely connected to progression in learning and to pupils' metacognition. Pupils' reflection on their own learning process and the content of this is seen to be improving the long-term effects of their knowledge acquisition and thereby contributing to the broad competences that education is aiming for:

Deep learning means that pupils use their ability to analyse, solve problems and reflect on their own learning in order to construct holistic and durable understanding. (NOU 2014:7 2014, p. 35) ${ }^{14}$

Deeper insights are developed when pupils connect the dots between areas of knowledge, and when they master a multitude of strategies for acquiring, sharing, and critically assessing knowledge. In NOU 2014: 7, 'deep learning' is described and contrasted to 'superficial learning' (p. 36). In deep learning, pupils relate new ideas and concepts to earlier knowledge and experiences, while in traditional or superficial learning this connection is not made. Furthermore, deep learning in this context is also associated with pupils' abilities to organise their own learning in accordance to their own worldviews, rather than treating learned material incoherently from this worldview so that it is not learned in a way that enables them to use it. When pupils look for patterns and underlying principles instead of memorising facts and carrying out procedures without understanding the how or why of them, this is an indicator of 'deep learning' in this context. This is also true if pupils evaluate new ideas and link them to conclusions as opposed to them having difficulties understanding new ideas which are different from those in their textbooks. Other examples are when pupils understand how knowledge emerges through dialogue and evaluate the logical grounds of an argument critically as opposed to treating facts and procedures as static knowledge, transferred from an all-knowing authority; or when pupils reflect on their own understanding and own learning process as opposed to memorising without reflecting on the purpose or their own learning strategies.

While the second Official Report (NOU 2015:8 2015) was centred on the knowledge base presented in NOU 2014:7, it focused more on different competences and curriculum construction. Competence is here differentiated into four areas: to have subject-specific competence; to practise metacognition and self-regulated learning; to communicate, cooperate and participate; to explore and create (NOU 2015:8 2015, pp. 8-10). ${ }^{15}$ 'Deep learning' is necessary for achieving these competences and subject learning is focused on serving this aim.

These ideas that are present in the new curricula have already been debated on many levels. A recent empirical study exploring the idea of deep learning argues that the background research referenced in the Official reports has a bias towards cognitive research (Østern et al. 2019). The authors claim the report ignores the body in favour of the mind: it has ignored research on play, embodied cognition, aesthetic processes of learning, studies from subject areas like art and physical education, and has also excluded post-colonial perspectives, and feminist and intercultural perspectives (Østern et al. 2019, p. 43). The cognitive research the reform is based on did not focus on children and young people, or school learning. Drawing from a broader range of subject areas, these authors discuss the idea of deep learning as learning that focuses on the 'whole pupil' and not just his or her cognitive capacities. A characteristic of deep learning according to Torchon is when learners are engaged on the personal level and also have the opportunity to develop the idea of who they are, or their own role in

14 See NOU 2014:7 2014, Table 3.1, p. 36. This is the author's translation from Norwegian. The last part of the definition is also presented in NOU 2015:8 2015, p. 14, only the word 'holistic' is removed.

15 Author's translation. See also the references to international developments regarding the description of 'competences for the 21st century' in NOU 2014:7 2014, pp. 111-29, referring among others to OECD, UNESCO and the 21st Century Skills Project. 
the world (Tochon 2010). For these authors, deep learning means working towards a holistic ecological understanding and responsibility for a sustainable future.

Furthermore, the concept used in the curriculum reform is completely different from what is meant by 'deep learning' in Artificial Intelligence research, for instance as described by LeCun et al. (2015). Here 'deep learning' is what allows computational models composed of multiple processing layers to learn representations of data with multiple layers of abstraction. Such methods have improved speech recognition, visual object recognition and other functions of artificial intelligence. Here, 'deep learning' means the ability to discover intricate structures in large data sets through algorithms so that computers can learn how to change their internal parameters used in the analysis of layers of information. While we cannot consider the full discussion here, it should be noted that there may be (unintended) similarities between deep learning in the curriculum reform and in AI. Gert Biesta has argued that educational theory with emphasis on self-regulated learning may be at odds with basic humanistic notions of education and Bildung. He therefore argues that a stronger position on 'teaching' is being taken at the expense of learning (Biesta 2016).

Drawing on Figure 1, we see this as being linked to international developments and 'policy borrowing', where international impulses are transferred to the national context (Steiner-Khamsi 2004; Karlsen 2006).

\section{Between School Subjects and Interdisciplinary Teaching}

The Official reports NOU 2014: 7 and NOU 2015: 8 differentiate between competence limited to specific subjects and competence of a more cross-curricular nature. This demonstrates that the school subjects are epistemic and political constructions that can be changed. NOU 2014:7 suggested that traditional school subjects should be merged into larger subject areas. Therefore, it was recommended that studies of religion and worldviews should be merged with social studies. The social studies subject is already having a broad scope in the Norwegian National Curriculum, including history, geography, sociology, political science, civics, minorities, technology, economy and more. The proposed merger was not carried forward when the government made their proposition to the Parliament (Kunnskapsdepartementet 2016). The subjects were kept intact, but the content was changed according to the new framework. Finally, as 'deep learning' is closely connected to progression, the subject curricula should not focus on adding new areas of knowledge, but more on how knowledge can be deepened and developed. In addition to what should be learned and why, the pedagogical focus on how learning is facilitated can thus be considered to be strengthened. Here a perspective from the general educational agenda has been explicitly expressed in one of the core elements for the studies of religion and worldviews in schools, which is 'Exploring religions and worldviews through different methods', as stated above.

These are the reasons for reducing the subject area content in the curricula and for looking into what is most useful for stimulating 'deep learning', meaning being able to use knowledge in new formerly unrelated contexts. Being able to utilise both broad competences and knowledge to address new challenges is seen as a skill needed to succeed in future life. Referring to the famous quote from the Chinese business magnate Jack Ma, in a speech at the World Economic Forum in 2018, 'everything we teach should be different from machines. For the past 200 years, education has been knowledge based, but machines will be smarter. Education is in big trouble if we do not change what we teach towards that which is uniquely human'. It could be noted that 'deep learning', as described in the Norwegian educational context now, is something which is indeed very different from 'deep learning' in machine learning, and it is characteristically and uniquely human, and thus something that machines will not do better. ${ }^{16}$ What is at stake here is the relevance of education in its classic form, in the school. Which knowledge and skills should be considered most important, and what is so relevant that it

16 Youtoube 24.1.2018: https://www.youtube.com/watch?v=pQCF3PtAaSg. 
should be given room in the subject curricula? This is negotiated, for instance, in connection with curricular reforms.

\section{Discussion of Results}

The research question raised in the introduction was: Which continuities and which changes are found when comparing studies of religion and worldviews in the previous and the new curricula? Here, our findings identify both continuity and change, both along the subject-specific-general-educational policy axis and along the national-international axis in Figure 1.

Since the subject structure of the former National Curriculum was retained, it is fair to say that the individual subjects were mainly changed by developments in education policy in general and not as much by subject-specific dynamics. However, the competence aims could be said to point towards a more explorative approach to religion and worldviews, both separately and in continuity with each other. New aims also include exploring religion and worldviews nationally and globally, which has not been stated so clearly before, and the point of exploring religion in media and popular culture is an example of a new subject-specific competence aim. There are examples of continuity also on the general level, as can be seen in the value base underpinning the education, based on Christian and Humanist heritage and tradition, updated in 2008 after the verdict in the European Court of Human Rights (Lied 2009). The value base is not specific to studies of religion and worldviews. Rather, it is a distributed responsibility across the entire educational system, building on values declared in the Constitution. ${ }^{17}$ The studies of religion and worldviews in particular have the role of familiarising pupils with how these values are anchored in different religions and worldviews, and in human rights.

The basic principles stating that 'Christianity, religion, worldviews, and ethics' is an 'ordinary subject' have not been formally changed, including the special mention of 'Christianity'. The requirement to allocate about half the lesson time to Christianity is still in force. The prominence of Christianity is even possible to detect in the description of the competence aims, mainly through the standard formulation 'Christianity, other religions and worldviews'. Judging from the comments round and public debate on the proposed curriculum text, it is striking how few conflicts the above-mentioned issues have raised. While there is still opposition to the privileged role Christianity has, it seems that this is seen more as a formal issue than a reality in school practice and even seen as a result of 'political showcasing' that may soon be abandoned as political coalitions change. In an international perspective, comparative studies of religion and worldview education in Europe display very different conceptions and tasks for these kinds of studies, even if there is also a tendency that the same supranational challenges are seen in all of these different contexts. As examples of supranational challenges, we can name secularisation, pluralisation of societies, and globalisation tendencies (Rothgangel et al. 2014-Northern Europe). Here, we encounter subject-specific discourses which can be found both in Norway and internationally, as seen in our model.

The above-mentioned comments round showed that there was criticism of the new design of the subject curricula, for example of the less detailed content. ${ }^{18}$ Here, there were critical comments about certain distinct content elements no longer being mentioned, such as 'Jesus' and 'Bible', historical perspectives on religions and so on. These and other criticisms are in part based on the subject-specific debate over competence aims and content, and in part on positions relating to principles of curriculum construction. This can therefore be considered a kind of negotiation between the subject-specific and general-educational poles of the axis in the model (Figure 1). To understand the thinking behind the new curriculum it is pivotal to understand the role of the core elements. They focus on key ideas, methods, and concepts in the individual subject, but there is also a strong intention to build bridges

17 The Norwegian Constitution, Article 2: 'Our values will remain our Christian and humanist heritage. This Constitution shall ensure democracy, a state based on the rule of law and human rights.' English version by the Norwegian Parliament: see https://www.stortinget.no/globalassets/pdf/english/constitutionenglish.pdf (Downloaded 26 March 2020).

18 As seen, for instance, in public feedback in the reform process: See, e.g., https://hoering-publisering.udir.no/348/uttalelser. 
between subjects. Here, ideas from the white paper about 'deep learning' and 'cross-disciplinary topics' are key to the interpretation of new subject-area didactics.

From now on teachers who are preparing for their lessons cannot merely use the competence aims for different key stages as the basis for their lesson planning, they also need to consider how these reflect the core elements, general values, cross-curricular topic areas and basic skills (reading, writing, oral skills, arithmetic, digital skills). Here there is a clear shift towards emphasising general educational principles more than previously in the planning of teaching. This demands local curriculum planning where the future evaluation of the curriculum will need to examine how it is interpreted at the school level in order to establish good quality of teaching and learning. The reason for this, in terms of aims and content, is that the new curriculum is much less detailed, with less than half the number of competence aims for each key stage compared to the former curriculum. For the upper secondary Religion and Ethics subject, there are now 14 competence aims, whereas there were 32 in the previous curriculum, while the number of lessons is the same (84). Combined with the new learning process-oriented concept of competence, the aim is a higher level of a learning taxonomy (as in Bloom's taxonomy). In theory this will facilitate pupils' understanding in such a way that it can be applied in new contexts. Here, the interdisciplinary topics are intended to create opportunities for understanding, utilising knowledge, and undertaking critical reflection. The core elements have significantly contributed to reducing the detailed content of the previous curricula. For religion and worldviews education, this could for instance mean that 'existential questions' and 'taking the perspective of the other' can help the teacher to avoid just teaching 'facts' about religion and worldviews, and rather find ways of facilitating 'deep learning'.

The cross-curricular topic areas are intended to introduce major contemporary and societal challenges towards which all individual subjects can contribute. If the subjects address the topic areas by drawing on their particular strengths, this will strengthen the relevance of the subjects for society, as well as for the individual pupils. We mentioned 'health and life skills' as a new cross-curricular topic area which opens possibilities for religion and worldview education to contribute through, for example, discussing ethical and existential issues. This new cross-curricular topic area could be seen as disconnecting existential questions from religion and worldview education, making them an aspect of wellbeing, or strengthening the relevance of religion and worldview education, through its ability to contribute to this topic. Zetterqvist \& Skeie has in another context discussed how religion can appear in surprising ways in schools under the auspices of promoting health, e.g., by introducing yoga and mindfulness (Zetterqvist and Skeie 2014). A specific task for religion education should then be to offer analytical tools for understanding different kinds of secular and spiritual meaning-making, as well as traditional religious forms and the intersections between them.

When it comes to the curriculum's emphasis on relevance and big ideas, we have already mentioned the international policy inspiration from science education. Similar ways of thinking have been launched in religion education, in particular from Exeter in the UK. Here, Barbara Wintersgill and co-authors have discussed what big ideas mean for religion education in an English context (Wintersgill 2015). It is argued that the pupils' experience of teaching has to be meaningful to them, so it is critical for education to be relevant, and therefore they identify six areas from which choices in the teaching content should be drawn. These are the six 'big ideas' for religion education. A listing of six main topic areas from which teaching content should be chosen (Wintersgill 2015, p. 15). We have arranged these in Table 2, similar to Table 1: 
Table 2. Core elements in Wintersgill (2015).

\begin{tabular}{ll}
\hline Core Element & Summary of Issues Included \\
\hline Continuity, change and diversity & $\begin{array}{l}\text { Religious and non-religious worldviews involve } \\
\text { interconnected patterns of beliefs, practices, and values }\end{array}$ \\
\hline Words and beyond & $\begin{array}{l}\ldots \text { to learn a vocabulary for expressing beliefs, feelings, and } \\
\text { religious experiences }\end{array}$ \\
\hline A good life & $\ldots$ religions offer ideas of what a good life is \\
\hline Making sense of life's experiences & $\begin{array}{l}\text { Many people have deeply felt experiences, which they may } \\
\text { refer to as being religious or spiritual, or simply part of what it } \\
\text { means to be human }\end{array}$ \\
\hline Influence, community, culture, and power & $\ldots$ to understand religions in communities and cultures \\
\hline The big picture & $\begin{array}{l}\text { Religions and non-religious worldviews provide } \\
\text { comprehensive accounts of how and why the world is as it is }\end{array}$ \\
\hline
\end{tabular}

While these are 'big ideas for religion education' in terms of criteria for constructing curricula and selecting teaching content, Freathy and John (2019) criticise that the above mentioned big ideas for religion and ethics are underpinned by a particular understanding of religions and worldviews. They find this to be too restricted compared to the many ideas that exist about religions and worldviews: 'if we accept that knowledge is culturally situated (...) we should encourage pupils to ask themselves about 'lenses' through which they view the world' (Freathy and John 2019, p. 32). They argue that the role of big ideas for religion education should be to highlight methodology and the relationship between ways of learning, learners, and what is learned. Therefore, there is a need for the study of religion and worldviews to incorporate considerations regarding both epistemological and methodological principles (Freathy and John 2019, p. 33). This has resulted in the following big ideas about the study of religion and worldviews (Table 3):

Table 3. Core elements in studies of religion and worldviews in Freathy and John (2019).

\begin{tabular}{cc}
\hline Core Element & Summary of Issues Included \\
\hline Encountering religion(s) and worldviews & Contested definitions and contents \\
\hline Encountering oneself & Reflexivity, reflectivity, and positionality \\
\hline Encountering methodologies and methods & Discernment and diversity \\
\hline Encountering the 'real world' & Relevance and transferability \\
\hline
\end{tabular}

While these examples from the English context may have had no direct influence on the construction of the new Norwegian curricula, they bear witness to the increased focus on 'big ideas' and 'core elements' as part of a broad international trend in educational policy and examples of the appropriation of this in specific subjects, among them religion and worldview education. Another example of similar thinking can be found in the present Swedish religion education curriculum, where the term 'förmågor' (English: 'ability' or, 'capacity') refers to long-term aims, not to be confused with Norway's curriculum competence aims. ${ }^{19}$ These examples highlight how important it is to see the different axes of our model (Figure 1) in relation to each other. When information flows in today's globalised world, crossing national borders, inter-connected ideas may develop through different kinds of networks that can lead to confusion. It is not unusual that concepts used in the field of education are less clearly established internationally, as is the case with 'deep learning' in education/computer science.

19 This cannot be analysed here, but an explanation of the function of 'förmågor' in the curriculum can be found in the official commentary material from the Swedish National Agency for Education: https://www.skolverket.se/download/18. 6bfaca41169863e6a6574ef/1553960691027/pdf2562.pdf (Downloaded 15 July 2020). 
The overlapping perspectives of the Norwegian curricular reform and international research developments, such as the example of big ideas, testifies to the supranational processes within educational policy, the 'international' in the model in Figure 1. From having a relevance in installing a personal morality, linked to a religion, education about religion and worldviews is now relevant for new purposes, according to developments related to secularisation and increased societal religion and cultural plurality across the European countries. This means that learners' backgrounds are in various religious and non-religious views; they also have peers of various religious or non-religious affiliations, and live in societies characterised by rapid social change and globalisation when it comes to worldviews and religion, as well as other aspects. To reference one specific example of supranational policy relating to the studies of religion and worldviews in schools, in their recommendations for teaching about religious and non-religious views, the Council of Europe states the following:

$(\ldots)$ the recommendation should be seen not only as having relevance to the classroom, but also to whole-school policies on diversity (contributing to intercultural education) and contact with local and wider communities, contributing to education for democratic citizenship, and with other schools. The recommendation was seen to be relevant to the ethos of schools, and not just to curriculum subjects". (Jackson 2014, p. 24)

This points out the relevance of teaching about religion and worldviews in classrooms for the support of a whole-school ethos, and for democratic citizenship, sustainability and public health and mastery of life. The aim is to develop cultural competence that enables pupils to become competent citizens in a pluralistic society with a functional democracy. This can even be considered a response to the question of why we should teach about religion and worldviews in schools at all, i.e., it is relevant for continued development as functioning democracies. This perspective on the role of religion and worldview education has been continued and strengthened through the new Norwegian curriculum.

In this article we have seen that there is continuity between the new Norwegian religion education curriculum and developments manifested in earlier curricula with respect to the main aims in religion and worldview studies, and that this is present in the international trends as formulated for example by Jackson (2014). The Norwegian context colours this with the continuing preoccupation with how to include the priority of national (Christian) heritage in the curriculum. Together with other school subjects, the changes are following international educational policy trends. Here, emphasis is on competence-orientation and relevance, less on teaching and learning of traditional subject content. Key terms are 'deep learning', 'big ideas' and 'cross-curricular societal challenges.' These developments open new possibilities for cooperation across school subjects. The continued relevance of teaching about religion and worldviews in schools is strengthened in the reform, because of the potential for significant contributions to the general aims of education now reflected in 'core elements', including for the continued development of a functioning democracy.

Author Contributions: Conceptualization, methodology, validation, writing-review and editing done by O.M.H.B. and G.S. Both authors have read and agreed to the published version of the manuscript.

Funding: This research received no external funding.

Conflicts of Interest: The authors declare no conflict of interest.

\section{References}

Aadnanes, Per Magne. 2012. Livssyn [Worldview], 4th ed. Oslo: Universitetsforlaget.

Alberts, Wanda. 2007. Integrative Religious Education in Europe: A Study-of-Religions Approach. Berlin: Walter de Gruyter.

Andersland, Inge. 2019. Religion Education, Religious and National Identity, and the Purpose of Education. An Idea Analysis of two Debates Concerning RE in the Norwegian Storting. Ph.D. thesis, MF-Norwegian School of Theology, Religion and Society, Oslo, Norway. Available online: https://mfopen.mf.no/mf-xmlui/ handle/11250/2624974 (accessed on 30 October 2020). 
Andreassen, Bengt-Ove, and Torjer A. Olsen. 2015. Religionsfaget i videregående skole. En læreplanhistorisk gjennomgang 1976-2006 [The religion subject in upper secondary education. A curricular-history review]. Prismet 66: 63-77. [CrossRef]

Anker, T. 2017. På tide å si farvel til verdensreligionene? [About time to say goodbye to world religions?]. In Religion i Skolen. Didaktiske Perspektiver på Religions- og Livssynsfaget. Edited by M. S. v. d. Lippe and S. Undheim. Oslo: Universitetsforlaget, pp. 25-34.

Biesta, Gert J. J. 2010. Good Education in an Age of Measurement: Ethics, Politics, Democracy. Boulder: Paradigm Publishers.

Biesta, Gert. 2016. The Rediscovery of Teaching: On robot vacuum cleaners, non-ecological education and the limits of the hermeneutical world view. Educational Philosophy and Theory 48: 374-92. [CrossRef]

Bråten, Oddrun Marie Hovde. 2018. World Views in Norwegian RE. In Challenging Life: Existential Questions as a Resource for Education. Edited by J. Ristiniemi, G. Skeie and K. Sporre. Münster: Waxmann, pp. 157-76.

Bråten, Oddrun M. H., and Judith Everington. 2019. Issues in the integration of religious education and worldviews education in an intercultural context. Intercultural Education 30: 289-305. [CrossRef]

Bråten, Oddrun M. H. 2013. Towards a Methodology for Comparative Studies in Religious Education. A Study of England and Norway. Münster: Waxmann.

Burawoy, Michael. 1991. The Extended Case Method. In Ethnography Unbound: Power and Resistance in in the Modern Metropolis. Berkley: University of California Press, pp. 271-87.

Freathy, Rob, and Helen C. John. 2019. Religious Education, Big Ideas and the study of religion(s) and worldview(s). British Journal of Religious Education 41: 27-40. [CrossRef]

Government. 2017. Core Curriculum-Values and Principles for Primary and Secondary Education; Oslo: Ministry of Education and Research. Available online: https://www.regjeringen.no/en/dokumenter/ verdier-og-prinsipper-for-grunnopplaringen---overordnet-del-av-lareplanverket/id2570003/ (accessed on 30 October 2020).

Gravem, Peder. 2004. KRL—Et Fag for Alle? KRL-Faget Som Svar på Utfordringer i en Flerkulturell Enhetsskole [KRL-A Subject for Everyone? The KRL Subject as an Answer to the Challenges in a Multicultural Comprehensive School]. Vallset: Oplandske bokforlag.

Grimmitt, Michael. 1987. Religious Education and Human Development: The Relationship between Studying Religions and Personal, Social and Moral Education. Great Wakering: McCrimmons.

Goodlad, John, and Z. Su. 1992. Organization of Curriculum. In Handbook on Research on Curiculum: A project of the American Educational Research Association. Edited by P. W. Jackson. New York: Macmillan Publishing Company, pp. 327-44.

Harlen, Wynne. 2010. Principles and Big Ideas of Science Education. Retrieved from Gosport, Hants. Hatfield: Association for Science Education.

Harlen, Wynne. 2015. Towards big ideas of science education. School Science Review 97: 97-107.

Iversen, Lars Laird. 2012. Learning to be Norwegian. A Case Study of Identity Management in Religious Education in Norway (Vol. 21). Münster: Waxmann Verlag.

Jackson, Robert. 2014. Signposts: Policy and Practice for Teaching about Religions and Non-Religious World Views in Intercultural Education. Strasbourg: Council of Europe Publishing.

Karlsen, Gustav. 2006. Utdanning, styring og marked: Norsk Utdanningspolitikk i et internasjonalt perspektiv. [Education, Governance and Market: Norwegian Educational Policy in an International Perspective]. Oslo: Universitetsforlaget.

Kallo, Johanna, and Risto Rinne. 2006. Supranational Regimes and National Education Policies: Encountering challenge. Turku: Finnish Educational Research Association.

Kooij, J. C. v. d. 2016. Worldview and Moral Education: On Conceptual Clarity and Consistency in Use. Ph.D. thesis, University of Amsterdam, Amsterdam, The Netherlands.

Kunnskapsdepartementet. 2016. Meld. St. 28 (2015-16) Fag-Fordypning-Forståelse. En fornyelse av Kunnskapsløftet [Subject-In-depth learning-Understanding. A renewal of the Knowledge Promotion Reform]; Oslo: Departementenes sikkerhets- og serviceorganisasjon. Available online: https://www.regjeringen.no/ contentassets/e8e1f41732ca4a64b003fca213ae663b/no/pdfs/stm201520160028000dddpdfs.pdf (accessed on 30 October 2020).

LeCun, Yann, Yoshua Bengio, and Geoffrey Hinton. 2015. Deep Learning. Nature 521: 436-44. [CrossRef] [PubMed] 
Lied, Sidsel. 2009. The Norwegian Christianity, Religion and Philosophy subject KRL in Strasbourg. British Journal of Religious Education 31: 263-76. [CrossRef]

NOU 2014:7. 2014. Elevenes Læring i Fremtidens Skole: Et Kunnskapsgrunnlag [Pupils' Learning in the School of the Future: A Knowledge Base]; Oslo: Det kongelige kunnskapsdepartement. Available online: https: //www.regjeringen.no/no/dokumenter/NOU-2014-7/id766593/?ch=1 (accessed on 30 October 2020).

NOU 2015:8. 2015. Fremtidens Skole: Fornyelse av fag og Kompetanser [The School of the Future: Subject Renewal and Competences]; Oslo: Departementenes sikkerhets- og serviceorganisasjon, Kunnskapsdepartementet. Available online: https:/www.regjeringen.no/contentassets/da148fec8c4a4ab88daa8b677a700292/no/pdfs/ nou201520150008000dddpdfs.pdf (accessed on 30 October 2020).

Østern, Tone P, Thomas Dahl, Axel Strømme, Jesper Aagard Petersen, Anna-Lena Østern, and Staffan Selander, eds. 2019. Dybdelæring. En flerfaglig, relasjonell og skapende tilnærming [Deep learning-An Interdisciplinary, Relational and Creative Approach]. Oslo: Universitetsforlaget.

Rothgangel, M., M. Rothgangel, and G. Skeie, eds. 2014. Religious Education at Schools in Europe. Part 3 Northern Europe. Göttingen: V\&R Unipress Vienna University Press.

Saler, Benson. 2009. Understanding Religion: Selected Essays. Berlin: Walter de Gruytier.

Sawyer, R. Keith. 2006. The Cambridge Handbook for Learning Sciences. Cambridge: Cambridge University Press.

Schjetne, Espen, and Ole Henrik Borchgrevink Hansen. 2019. Emplotting a privileged position. The construction of the history of secular humanism in Norwegian religious education textbooks. British Journal of Religious Education, 1-11. [CrossRef]

Skeie, G. 2007. Religion and Education in Norway. In Religion and Education in Europe: Developments, Contexts and Debates. Edited by R. Jackson, S. Miedema, W. Weisse and J.-P. Willaime. Münster: Waxmann, pp. 221-42.

Skeie, G. 2020. Religious education research-Does it prepare us for the future? In Facing the Unknown Future. Religion and Education on th Move. Edited by I. t. Avest, C. Bakker, J. Ipgrave, S. Leonard and P. Schreiner. Münster: Waxmann, pp. 47-72.

Skeie, G., and O. M. H. Bråten. 2014. Religious Education at Schools in Norway. In Religious Education at Schools in Europe. Part 3: Northern Europe. Edited by M. Rothgangel, M. Jäggle and G. Skeie. Göttingen: V\&R unipress Vienna University Press, pp. 203-30.

Steiner-Khamsi, Gita, ed. 2004. The Global Politics of Educational Borrowing and Lending. New York: Teacher College Press, Colombia University.

Stone-Wiske, Martha. 1998. Teaching for Understanding. Linking Research with Practice. San Francisco: Jossey-Bass Inc. Taves, Ann. 2020. From Religious Studies to Worldview Studies. Religion 50: 137-47. [CrossRef]

Tochon, Francois Victor. 2010. Deep Education. Journal for Educators, Teachers and Trainers 1: 1-12.

Utdanningsdirektoratet. 2019. Udir-1-2019. Fag- og timefordeling og tilbudsstruktur for Kunnskapsløftet [Subject and Lesson Allocation Plan and Structure for the Knowledge Promotion Reform]. Oslo: Utdanningsdirektoratet.

Utdanningsdirektoratet. 2020. Lxreplan i Religion og etikk (RE) [Curriculum in Religion and Ethics (RE). Oslo: Utdanningsdirektoratet, Available online: https://www.udir.no/lk20/rel01-02 (accessed on 30 October 2020).

Wintersgill, Barbara, ed. 2015. Big Ideas for Religious Education. Exeter: University of Exeter.

Zetterqvist, Kirksten Grönlien, and Geir Skeie. 2014. Religion i skolen: Her, der og hvor-som-helst? Norsk Pedagogisk Tidsskrift 98: 304-15.

Publisher's Note: MDPI stays neutral with regard to jurisdictional claims in published maps and institutional affiliations.

(C) 2020 by the authors. Licensee MDPI, Basel, Switzerland. This article is an open access article distributed under the terms and conditions of the Creative Commons Attribution (CC BY) license (http://creativecommons.org/licenses/by/4.0/). 